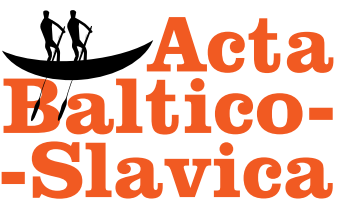

Acta Baltico-Slavica, 38 SOW, Warszawa 2014

DOI: $10.11649 /$ abs. 2014.020

\title{
Ewa Golachowska
}

Instytut Slawistyki PAN

Warszawa

ewa.golachowska@wp.pl

\section{Anna Engelking, Kołchoźnicy. Antropologiczne studium tożsamości wsi białoruskiej przełomu XX i XXI wieku. Toruń: Wydawnictwo Naukowe Uniwersytetu Mikołaja Kopernika}

Monografia Anny Engelking Kołchoźnicy. Antropologiczne studium tożsamości wsi białoruskiej przełomu XX $i$ XXI wieku zawiera wyniki badań prowadzonych przez autorkę przez dwadzieścia lat na terenie Białorusi Zachodniej i Wschodniej, samodzielnie oraz przez grupy studenckie przygotowane przez badaczkę. Długie pobyty wśród informatorów, powroty do zaprzyjaźnionych rodzin z nowymi przemyśleniami i pytaniami, zaowocowały pełnymi treści rozmowami. Bliskie relacje z rozmówcami, zrozumienie i empatia są widoczne na każdej karcie tej książki. Jak pisze autorka „etnograficzna opowieść jest wspólnym dziełem badacza i badanych” (s. 37), dlatego w swojej pracy Anna Engelking oddaje głos rozmówcom. W zakończeniu autorka pisze niezmiernie ważne i poruszające zdanie:

Zabierają w niej głos ludzie pozbawieni tego prawa przez długie lata funkcjonowania totalitarnej machiny "państwa robotników i chłopów«, dla którego byli poddaną manipulacji, eksploatacji i eksterminacji ludzką masą; podobnie prawa głosu nie mieli wcześniej, przez stulecia pańszczyzny. Dlatego, pisząc moją «etnograficzną opowieść» z perspektywy mużyków-kołchoźników - tak bowiem, nie inaczej, pojmuję swoje zadanie antropologa robiłam to z nadzieją, że przyczyniam się w ten sposób do przywracania im - i nam - tego niesprawiedliwie odebranego i niesłusznie zapomnianego głosu (s. 762). 
Długi czas spędzony na badanym terenie skutkuje możliwością spojrzenia na problem badawczy od wewnątrz i umiejętnością odkrycia pojęć ważnych dla przedstawicieli badanych wspólnot. Jest to jedno z ważniejszych założeń metodologicznych, od lat obecne w pracach autorki. Właśnie dlatego odpowiedzi na główne pytania stawiane w pracy, o sposób konstruowania zbiorowej tożsamości białoruskich kołchoźników, przynoszą relacje, w których autorka szuka istotnych dla rozmówców norm, reguł i podstawowych opozycji semiotycznych.

Rozmówcami autorki są przedstawiciele starszego pokolenia mieszkańców wsi białoruskiej. Niektórzy z nich pamiętają przedwojenne realia i tworzenie kołchozów po II wojnie światowej, inni swą wiedzę o tych wydarzeniach czerpią z tego, co zachowało się w pamięci zbiorowej.

Monografia Kołchoźnicy zbudowana jest z czterech części: I. „W kołchozie”; II. „Kołchoźnik i pan”; III. „Chłopi versus Żydzi”, odrębność grupowa jako fundament tożsamości; IV. „Wobec Boga”. Każda z części mówi o innym elemencie budującym tożsamość współczesnych mieszkańców białoruskich wsi kołchozowych.

W krótkiej recenzji nie sposób omówić wszystkich wątków pojawiających się w pracy.

Z konieczności pokażę tylko te, które moim zdaniem, są najważniejsze dla zrozumienia specyfiki kultury białoruskiej wsi kołchoźniczej.

W części pierwszej znajdujemy analizę opowieści dotyczących początków kolektywizacji, historie pokazujące przemoc władzy i bezradność wiejskiej ludności (Rozdział I. „Bez kołchoza życia nie ma. Narracja o końcu i początku jako mit założycielski”). Niezwykle wstrząsające historie ukazują ludzkie dramaty wynikające z konieczności oddania do kołchozu własnego pola, ogrodu i inwentarza. Na Białorusi Zachodniej narracje te dotyczą wspomnień stosunkowo świeżych i wydarzeń, które rozmówcy autorki pamiętają z dzieciństwa, co wprowadza osobiste wątki do tych relacji. W wypowiedziach z Białorusi Wschodniej jest mniej komponentu osobistego (wydarzenia nie dotyczyły bezpośrednio rozmówców, tylko ich rodziców), ale relacje przedstawiają znacznie bardziej dramatyczny przebieg kolektywizacji, której towarzyszyły głód, strach i terror. Pamięci o tych tragediach czas nie zatarł.

Historie, które mówią o końcu pewnego porządku, o końcu znanego i bezpiecznego świata, stanowią punkt wyjścia do opowieści, w których czytamy o pogodzeniu się z losem i stopniowej akceptacji nowej rzeczywistości (Rozdział II. „Kołchoz musi być. Długie trwanie wzorca feudalnego"). Nowa rzeczywistość jest oswajana, a w nowe formy wpisują się stare treści. Z wysłuchanych i zapisanych przez autorkę opowieści kołchoźników wyłania się zhierarchizowany obraz świata społecznego. Na jego szczycie stoi najwyższa władza, którą w kołchozie reprezentuje predsiedaciel kołchoza, potem urzędnicy niżsi rangą. Najniższą pozycję zajmują kołchoźnicy - ludzie roboczy, których zadaniem jest codzienna praca. Akceptują oni sytuację, w której przedstawiciele władzy wymagają posłuszeństwa i strzegą porządku, ale również troszczą się i opiekują mieszkańcami kołchozowej wsi. W sytuacji, gdy poczucie bezpieczeństwa i możliwość przetrwania są większą wartością 
niż możliwość sprzeciwu, pozycja władzy staje się stabilna i niepoddawana dyskusji. Anna Engelking analizuje trwałość we współczesnej kulturze kołchozowej wzorców feudalnych, które nadal kształtują tożsamość białoruskich kołchoźników. Podobnie, jak w systemie feudalnym, działają silne, może nawet symbiotyczne związki pomiędzy cerkwią lub kościołem, a kołchozową administracją.

Ponieważ jedno z kluczowych pytań dotyczących tożsamości brzmi „kim są inni” (s. 27), autorka w dwóch kolejnych częściach pokazuje kluczowe dla samoidentyfikacji białoruskich kołchoźników figury: pana i żyda ${ }^{1}$, obie skonfrontowane z postacią kołchoźnika.

W części II. zaty tułowanej „Kołchoźnik i pan” Anna Engelking omawia zagadnienia odrębności grupowej chłopów. Jej fundamentem jest opozycja postaci chłopa i pana. Pomimo faktu, że powstanie kołchozów wyznaczyło kres ery panów, koncept pana jest stale obecny w opowieściach kołchoźników. Postać pana wyłania się zarówno z narracji dotyczących przeszłości, jak i z współczesnych opowieści. Obecnie panem jest zwierzchnik kołchozu i inni urzędnicy stojący wyżej od kołchoźnika w hierarchii społecznej. Stary porządek zostaje wypełniony przez nowe osoby, które podejmują dawne funkcje. Rolą pana jest nadzorowanie pracy, rolą chłopa jej wykonywanie. Ten obraz wyraźnie pokazuje, jak bardzo teraźniejszość zakorzeniona jest w przeszłości.

Rozdział III. „Chłop i pan przed kołchozem i w kołchozie, czyli o współczesnej pańszczyźnie" pokazuje, że w opowieściach kołchoźników przetrwał nie tylko obraz pana, ale i pamięć o pańszczyźnie. Pochodzi ona z ustnych przekazów i mówi o robocie przez większość dni tygodnia na dworskim polu i pracy na własnym skrawku ziemi jedynie nocą. Te opowieści są zestawiane przez autorkę z narracjami o ciężkiej pracy na kołchozowych polach i możliwością zajęcia się własnymi uprawami tylko nocą. W relacjach tych uderza fakt, że pańszczyzna rozumiana jest jako wszelka praca na cudzej ziemi pańskiej lub kołchozowej i niekoniecznie musi się odnosić do dawnej renty feudalnej. Ważniejsze od prawdy historycznej okazują się językowe związki z rzeczownikiem pan, a więc z kimś, kto ma władzę lub posiada majątek (s. 200). O pańszczyźnie kołchoźnicy mówią z żalem i poczuciem krzywdy, ale przecież jednocześnie ciężka fizyczna praca na roli nadaje sens ich życiu i jest powodem do dumy.

Opisana powyżej dychotomiczna opozycja pan/chłop nie pokazuje całego zróżnicowania społecznego dawnych wsi białoruskich. Osobne miejsce zajmowała w nim, zwłaszcza na Grodzieńszczyźnie, drobna szlachta. Autorka poświęca temu zagadnieniu wiele miejsca w rozdziale IV. „Chamy i Pany. Między strukturą, a communitas”. Drobna szlachta mająca podobny do chłopskiego status ekonomiczny, ale zupełnie inny status społeczny, została włączona do kołchozu tak, jak chłopi. Wprawdzie czas

${ }^{1}$ Za Anną Engelking (s. 34-36) stosuję małą literę, ponieważ nazwa własna odnosi się tu nie do narodowości, ale konfesji. Autorka konsekwentnie używa małej litery, pisząc o polakach, ruskich i białorusach. 
nie zatarł pamięci o różnicach kulturowych i socjalnych dzielących mieszkańców szlacheckich okolic i mużyckich wiosek, jednak wydaje się, że dawne antagonizmy zostały unieważnione i zniwelowane.

Chłopów i drobną szlachtę [...] jednoczy praca na ziemi - w tych samych kołchozach i sowchozach. To ona odróżnorodnia odrębności i daje kołchoźnikowi poczucie wspólnej tożsamości, niezależnie od historycznego dystansu społecznego, dychotomizujących stereotypów i świadomości różnic w obrębie tej wspólnoty. Bez względu na to, kim byli kiedyś - dziśs to mużyki-kołchoźniki i szlachta-kołchoźniki (s. 324) - pisze autorka.

Owej pracy, która nie tylko jednoczy ludzi, ale przede wszystkim buduje poczucie godności kołchoźników, Anna Engelking poświęca rozdział V. „Proste robocze ludzie. Praca na ziemi jako wartość konstytutywna dla tożsamości”. Jednym z ważniejszych fragmentów jest jego ostatnia cześć „Chłop sobie panem, czyli wzór dobrego gospodarza przed kołchozem i w kołchozie”. Z opowieści o przedkołchozowej przeszłości wyłania się postać kułaka, który sam pracuje na roli jak inni chłopi, ale tak jak pan jest właścicielem swojej ziemi. Uosabia on chłopski ideał i wzór do naśladowania. Realizacja tego wzoru w kołchozowej rzeczywistości nie jest łatwa, lecz współczesne zmiany czasem dają możliwość wykupienia lub dzierżawy ziemi. Możliwości te bywają skwapliwie wykorzystywane i jeśli ziemia wraca w ręce chłopów, to praca na niej daje im względną zamożność, a to sprawia, że kołchoźnicy na powrót stają się gospodarzami.

Trzecia część monografii zatytułowana „Kołchoźnik i żyd” poświęcona jest zagadnieniom związanym z postacią żyda, utrwaloną w pamięci zbiorowej mieszkańców wsi białoruskich. Opowieści kołchoźników zawarte w tej części nie układają się w spójną całość, lecz prezentują różnorodność postaw wobec żydów, skomplikowane choć bardzo często dobre stosunki sąsiedzkie oraz cały wachlarz stereotypów i uprzedzeń. Pojawiają się postacie żydów żyjących z handlu lub rzemiosła, ale także takich, którzy podjęli się uprawy ziemi. Żydzi są z jednej strony „obcymi”, mieszkającymi raczej w mieście niż na wsi lub wręcz osobami prowadzącymi życie wędrowne, z drugiej stanowią część znanej od pokoleń rzeczywistości społecznej. Jednak jako człowiek „niezakorzeniony” żyd jest przeciwieństwem autostereotypu kołchoźnika. Jego obcość wzmacnia różnica religijna, sprowadzana najczęściej do braku chrztu. Pojawiające się w tej części pracy wątki różnic religijnych zostają wyczerpująco omówione w ostatniej IV. części zatytułowanej „Wobec Boga”.

Część czwartą otwiera cytat „Każda nacja swoju wieru ma”. To zdanie jest niezwykle ważne dla społeczności, którą charakteryzuje wielość religii, języków i nacji. Centralnym zagadnieniem jest dla białoruskich kołchoźników kwestia chrztu. Dzieje się tak, ponieważ to chrzest przypisuje jednostkę do właściwej nacji i nie ma znaczenia późniejsze zaangażowanie w życie wspólnot religijnych. Nacje chrześcijańskie (wyznania religijne) posługują się właściwymi sobie językami, kreślą znak krzyża na sposób katolicki lub prawosławny. Odwieczne współistnienie różnych wyznań na 
tym terenie sprawia, że ich współżycie układa się bezkonfliktowo, a status jest równorzędny. W tę mozaikę włącza się także wyznania niechrześcijańskie, poszerzając definicję ludzi wierzących o żydów, którzy też mają swój wariant „wiary” (s. 607). Taka charakterystyka religijności społeczności pogranicza właściwa jest zwłaszcza dla Grodzieńszczyzny. Na Białorusi Wschodniej sytuacja jest inna. Obszar ten postrzegany jest często jako przestrzeń pozbawiona świątyń, a w konsekwencji również ludzi wierzących. Jednak z opowieści kołchoźników zamieszkujących Wschodnią Białoruś wyłania się inny obraz. Wprawdzie odnajdziemy wypowiedzi osób niepewnych nazwy swej wiary (choć to teren zdominowany przez prawosławie), jednak ten brak rozeznania (wiedzy) nie jest tożsamy z brakiem wiary i obojętnością religijną. Często wiara ta sprowadza się do wypowiadania magicznych formuł wobec sacrum lub kreślenia znaku krzyża w celu zapewniania sobie pomyślności i nie ma nic wspólnego z nauką żadnego Kościoła chrześcijańskiego, jednak życie bez wiary wydaje się rozmówcom niemożliwe ponieważ „człowiek jest istotą, która wierzy w Boga” (s. 756).

Książka Anny Engelking w pełni odpowiada na postawione przez autorkę na początku pytanie o tożsamość białoruskich kołchoźników poprzez rekonstrukcję własnego obrazu widzianego od wewnątrz badanego świata. Autorka pokazuje, że jej rozmówcy postrzegają siebie, konstruując i rekonstruując wyraziste opozycje: chłop/ pan, chrześcijanin/żyd, wierzący/niewierzący.

Niezwykłym walorem książki jest umiejętność ukazania związków przeszłości z teraźniejszością. W opowieściach kołchoźników wyraźnie widać, jak współczesność zanurzona jest w przeszłości, jak dawne porządki społeczne pomimo zmian politycznych i ekonomicznych, mimo tragicznych doświadczeń historii XX w. - totalitaryzmu i Zagłady, są zakonserwowane i wciąż obecne w ludzkiej świadomości. Pomimo lat ateizacji i pracy w kołchozie, nieprzynoszącej ani satysfakcji, ani dobrobytu, do najważniejszych wartości kołchoźników, definiujących ich tożsamość, wciąż należą praca na roli i wiara w Boga.

Niezwykłe bogactwo opowieści zawarte w książce, będzie służyć badaczom różnych dyscyplin, gdyż znajdą tu materiał antropologowie, etnografowie, historycy, socjologowie religii i socjolingwiści. Wnikliwemu czytelnikowi pomoże w zrozumieniu specyfiki kultury współczesnego białoruskiego społeczeństwa, którego obecna i zapewne przyszła tożsamość zakorzeniona jest w przeszłości. Książka rozbudza ciekawość i prowokuje do stawiana pytań, o oblicza lokalnych społeczności na innych obszarach postradzieckich.

\section{Bibliografia}

Engelking, A. (2012). Kołchoźnicy: antropologiczne studium tożsamości wsi białoruskiej przełomu XX i XXI wieku. Toruń: Wydawnictwo Naukowe Uniwersytetu Mikołaja Kopernika. 


\title{
Anna Engelking, Kołchoźnicy: antropologiczne studium tożsamości wsi białoruskiej przełomu XX i XXI wieku
}

\begin{abstract}
Summary
The monograph by Anna Engelking Kolkhoz members. Antropological study of identity in the Belorussian country at the turn of $20^{\text {th }}$ and $21^{\text {st }}$ centuries contains results of the research thet has been carried out for twenty years in Belarus. The author poses questions concerning the identity of Belarussian Kolkhoz members formed by themselves and shows that it is based on clear contrasts: peasant / landlord, Christian / Jew, believing / unbelieving. These contrasts are rooted in the past but the author shows that the contemporary Belorussian country is immersed in the past and earlier social order is still present in people's minds despite political and economic changes.
\end{abstract}

Keywords: Belarus; anthropology; identity 